\title{
Effect of Irrigation and Nitrogen on Production Potential of Sorghum (Sorghum bicolor L.) under South Gujarat Condition
}

\author{
Diksha Tajane $^{1 *}$ V. P. Usadadia ${ }^{2}$, Dipak Borase ${ }^{1}$ and Sangita Sawadhkar ${ }^{3}$ \\ ${ }^{1}$ Department of Agronomy, N. M. College of Agriculture, Navsari Agricultural University, \\ Navsari-396450, India \\ ${ }^{2}$ Department Soil and Water Management Research Unit, Navsari Agricultural University, \\ Navsari-396450, Gujarat, India \\ ${ }^{3}$ Department of Agronomy, College of Agriculture, Dr. P. D. K. V, Akola-444004, India
}

*Corresponding author

\section{A B S T R A C T}

\section{Keywords \\ Nitrogen application, coastal areas, irrigation levels}

\section{Article Info}

Accepted:

20 August 2019

Available Online:

10 September 2019
A field experiment entitled "Response of rabi sorghum (Sorghum bicolor L.) on different levels of irrigation, nitrogen and banana pseudostem sap and its residual effect on summer greengram (Vigna radiata L.) under South Gujarat condition" was carried out during rabi season of 2016-17 and 2017-18 at college farm of Soil and Water Management Research Farm, Navsari Agricultural University, Navsari. The soil was clayey in texture, rich in organic carbon, medium in available nitrogen, $\mathrm{P}_{2} \mathrm{O}_{5}$ and $\mathrm{K}_{2} \mathrm{O}$ with alkaline in reaction $(\mathrm{pH}$ 7.8). Total twelve treatment combinations, consisting of four irrigation schedule based on IW:CPE ratio $\left(I_{1}=0.4, I_{2}=0.6\right.$ and $\left.I_{3}=0.8\right)$ and three nitrogen levels $\left(N_{1}=60 \mathrm{~kg} \mathrm{~N} \mathrm{ha}^{-1}, \mathrm{~N}_{2}=\right.$ $80 \mathrm{~kg} \mathrm{~N} \mathrm{ha}{ }^{-1}$ and $\mathrm{N}_{3}=100 \mathrm{~kg} \mathrm{~N} \mathrm{ha}^{-1}$ ) were tested in a split plot design with four replications. The results indicated that scheduling irrigation at an IW:CPE ratio of 0.8 recorded significantly higher values of almost all the growth characters, yield attributes as well as seed and stover yields of sorghum over 0.6 and 0.8 IW:CPE ratios and remained statistically at par with IW:CPE ratio of 0.8 . Days to $50 \%$ flowering and maturity were delayed under this IW:CPE ratio. Whereas, higher WUE was obtained when crop was irrigated at 0.4 IW:CPE ratio. Almost all the growth characters, yield attributes, seed and stover yields were found significantly higher when crop has given nitrogen application at $100 \mathrm{~kg} \mathrm{~N} \mathrm{ha}^{-1}$ than that over lower dose of nitrogen.

\section{Introduction}

A field experiment was conducted during 2016-17 to 2017-18 at college farm of Soil and Water Management Research Farm, Navsari Agricultural University, Navsari Gujarat to study the effect of different levels of irrigation and nitrogen on production potential and profitability of Sorghum in saline soil of coastal areas of south Gujarat. The field experiment was laid out in split plot technique with four replications, comprising three levels of irrigation (0.4, 0.6 and 0.8 IW/CPE) and three nitrogen levels $(60,80$ and $100 \mathrm{~kg} \mathrm{~N} \mathrm{ha}^{-1}$ ). The results indicated that scheduling irrigation at an IW:CPE ratio of 0.8 
recorded significantly higher values of almost all the growth characters, yield attributes as well as seed and stover yields of sorghum over 0.6 and 0.8 IW:CPE ratios and remained statistically at par with IW:CPE ratio of 0.8 such as plant height at harvest, leaf area index at 90 DAS, no. of internodes, grain yield, field water use efficiency and sorghum equivalent yield. Among the irrigation levels, both 0.6 and $0.8 \mathrm{IW} / \mathrm{CPE}$ were remained at par with each other and found to be significantly superior over 0.4 IW/CPE (I1) for growth and yield attributing parameters Treatment $\mathrm{I}_{2} \mathrm{~N}_{3}$ recorded significantly higher seed yield (972 $\mathrm{kg}$ ha-1), net realization ( $2,15,052$ ha-1) and benefit cost ratio (2.81).

Sorghum (Sorghum bicolor L.) is a drought resistant crop among the major cereals and the fifth most important cereal in the world after wheat, rice, maize and barley. It is considered as king of millets and staple food and fodder crop of the world's poor and most foodinsecure population, located primarily in the arid and semi-arid tropics. Sorghum grain contains $56-73 \%$ starch, $11.3 \%$ protein and $3.3 \%$ fat. Sorghum fodder is considered as an essential feeds for the livestock, which can help in maintaining good health of cattle and contains more than $50 \%$ digestible nutrients with $8 \%$ protein, $2.5 \%$ fat and $45 \%$ nitrogenfree extract. Its dietary value is equivalent to corn that way animals enjoy well due to its deliciousness and juicy character (Mehmood et al., 2008). It grown on 43.81 million ha area in the world, producing about 65.42 million tonnes grain with an average yield of $1523 \mathrm{~kg}$ $\mathrm{ha}^{-1}$. India and USA have largest share of global sorghum area, while the maximum production of sorghum occur in the USA. India presently produces about 5.54 million tonnes of sorghum grain from area of 6.16 million ha and productivity of $884 \mathrm{~kg} \mathrm{ha}^{-1}$.

Among the different factors affecting yield, water management and nitrogen play an important role for enhancing yield. Water is the scare natural resource and availability of irrigation water is limited therefore, irrigation water should be utilized most efficiently by scheduling irrigation based on IW:CPE ratio. Application of nitrogen is another key factor affecting yield per unit area results in lower yield and hence optimum plant population produces maximum yield.

Precise information regarding appropriate schedule of irrigation and nitrogen requirements for rabi sorghum is very limited. Keeping in view the above considerations, comprehensive research programme planned to study the judicious use of irrigation water which may provide information on not only water use by crop but also when to irrigate and to find out optimum nitrogen requirement for sorghum with the following broad objectives.

For exploiting its maximum yield potentiality and efficient utilization of light, land, water and inputs, optimum plant population is vital factor for rabi sorghum. Keeping in view the above considerations, comprehensive research programme was plan to study the judicious use of irrigation water and to determine the suitable dose of nitrogen for rabi sorghum with the following broad objectives.

\section{Materials and Methods}

A field experiment was carried out during rabi season of 2016-17 and 2017-18 at college farm of Soil and Water Management Research Farm, Navsari Agricultural University, Navsari. The soil was clayey in texture, rich in organic carbon, medium in available nitrogen, $\mathrm{P}_{2} \mathrm{O}_{5}$ and $\mathrm{K}_{2} \mathrm{O}$ with alkaline in reaction $(\mathrm{pH}$ 7.8). Total sixteen treatment combinations, consisting of four irrigation schedule based on IW: CPE ratio $\left(\mathrm{I}_{1}=0.4, \mathrm{I}_{2}=0.6\right.$ and $\left.\mathrm{I}_{3}=0.8\right)$ and three row spacing $\left(\mathrm{N}_{1}=60 \mathrm{~kg} \mathrm{~N}^{-1}, \mathrm{~N}_{2}=80\right.$ $\mathrm{kg} \mathrm{N} \mathrm{ha}^{-1}$ and $\mathrm{N}_{3}=100 \mathrm{~kg} \mathrm{~N} \mathrm{ha}^{-1}$ ) were tested in a split plot design with four replications to 
ascertain optimum IW:CPE ratio for scheduling irrigation, to find out optimum nitrogen dose, to work out yield, WUE of irrigation and nitrogen dose on yield of rabi sorghum.

\section{Results and Discussion}

\section{Days To 50\% Flowering}

The data pertaining to days to $50 \%$ flowering as influenced by different IW:CPE ratio and spacing are summarized in Table 1. Irrigation scheduled at $0.4 \mathrm{IW}: \mathrm{CPE}$ ratio $\left(\mathrm{I}_{1}\right)$ recorded significantly less number of days (44.16) for $50 \%$ flowering whereas, irrigation scheduled at 1.0 IW:CPE ratio $\left(\mathrm{I}_{3}\right)$ taken significantly more number of days (53.11) for $50 \%$ flowering. lower dose of nitrogen at $60 \mathrm{~kg} \mathrm{~N}$ $\mathrm{ha}^{-1}\left(\mathrm{~N}_{1}\right)$ recorded significantly less number of days (45.77) for $50 \%$ flowering whereas, higher dose of nitrogen of $100 \mathrm{~kg} \mathrm{~N} \mathrm{ha}{ }^{-1}\left(\mathrm{~N}_{3}\right)$ taken significantly more number of days (49.90) for 50\% flowering. Hugar et al., 2010 reported that lower dose of nitrogen application might be increase higher water and nutrient absorbed by plants, thus decrease in days in 50\% flowering.

\section{Days to maturity}

The data regarding days to maturity on pooled basis as influenced by different IW:CPE ratios and nitrogen dose are presented in Table 1. Irrigating the crop as per $0.4 \mathrm{IW}: \mathrm{CPE}$ ratio $\left(\mathrm{I}_{1}\right)$ taken significantly less number of days for maturity (85.91) which was on par with IW:CPE ratio of $0.6\left(\mathrm{I}_{2}\right)$ while, sorghum irrigated at 0.8 IW:CPE ratio $\left(\mathrm{I}_{3}\right)$ took significantly more (91.98) number of days to maturity. Whereas minimum days to maturity were found to be significant due to the lower level $\left(\mathrm{N}_{1}\right.$ i.e., $\left.60 \mathrm{~kg} \mathrm{~N} \mathrm{ha}{ }^{-1}\right)$ of irrigation (84.79), Patel et al., 2010.

\section{Length of ear head}

The mean data on length of ear head as influenced by different IW:CPE ratio and nitrogen dose are furnished in Table 1. Significantly the highest length of ear head of sorghum plant $(23.60 \mathrm{~cm})$ was recorded when rabi sorghum was irrigated at $0.8 \mathrm{IW}: \mathrm{CPE}$ ratio $\left(I_{3}\right)$.

Significantly the lowest ear head length (20.73) was observed under 0.4 IW: CPE ratio $\left(\mathrm{I}_{1}\right)$. Application of nitrogen of $100 \mathrm{~kg} \mathrm{~N} \mathrm{ha}^{-1}$ $\left(\mathrm{N}_{3}\right)$ produced significantly the highest ear head length (24.28).

Significantly the lowest length of ear head (21.40) was observed under 60 and $80 \mathrm{~kg} \mathrm{~N}$ $\mathrm{ha}^{-1}\left(\mathrm{~N}_{1}\right.$ and $\left.\mathrm{N}_{2}\right)$. Patel 2005 reported that optimum availability of moisture at 0.8 IW:CPE ratio without any stress and higher dose of nitrogen increases ear head length per plant.

\section{Seed yield per hectare}

A perusal of data on seed yield per hectare as influenced by different IW:CPE ratio and nitrogen dose are furnished in Table 2. The results revealed that significantly higher seed yield of $3317 \mathrm{~kg} \mathrm{ha}^{-1}$ was produced under IW:CPE ratio $0.6 \quad\left(I_{2}\right)$ and it was found statistically on same bar with $\mathrm{I}_{3}$. Significantly minimum seed yield of $2734 \mathrm{~kg} \mathrm{ha}^{-1}$ was recorded under IW:CPE ratio $0.4\left(\mathrm{I}_{1}\right)$. Seed yield per hectare differed significantly due to different levels of nitrogen. Application of nitrogen at $100 \mathrm{~kg} \mathrm{~N} \mathrm{ha}^{-1}\left(\mathrm{~N}_{3}\right)$ produced significantly higher seed yield of $3307 \mathrm{~kg} \mathrm{ha}^{-1}$. Significantly lower seed yield of $2763 \mathrm{~kg} \mathrm{ha}^{-1}$ recorded under lower dose of nitrogen i.e., 60 $\mathrm{kg} \mathrm{N} \mathrm{ha}{ }^{-1}\left(\mathrm{~N}_{1}\right)$. Patel et al., 2010 found that optimum availability of moisture at 0.8 IW:CPE ratio. 
Table.1 Effect of irrigation and nitrogen on days to $50 \%$ flowering, days to maturity and length of ear head of sorghum (pooled)

\begin{tabular}{|c|c|c|c|c|}
\hline Tr No. & Treatments & $\begin{array}{c}\text { Days to } 50 \% \\
\text { flowering }\end{array}$ & $\begin{array}{l}\text { Days to } \\
\text { maturity }\end{array}$ & $\begin{array}{c}\text { length of ear } \\
\text { head }\end{array}$ \\
\hline & Irrigation: (I) & & & \\
\hline $\mathbf{I}_{1}$ & 0.4 IW:CPE ratio & 44.16 & 85.91 & 20.73 \\
\hline $\mathbf{I}_{2}$ & 0.6 IW:CPE ratio & 46.81 & 87.41 & 22.75 \\
\hline \multirow[t]{5}{*}{$\mathbf{I}_{3}$} & 0.8 IW:CPE ratio & 53.11 & 91.98 & 23.60 \\
\hline & SEm \pm & 0.68 & 0.76 & 0.25 \\
\hline & $\mathrm{CD}(\mathrm{P}=0.05)$ & 2.09 & 2.35 & 0.76 \\
\hline & $\mathrm{CV} \%$ & 9.77 & 5.98 & 7.61 \\
\hline & Nitrogen: $(\mathbf{N})$ & & & \\
\hline $\mathbf{N}_{1}$ & $60 \mathrm{~kg} \mathrm{~N} \mathrm{ha}^{-1}$ & 45.77 & 84.79 & 21.40 \\
\hline $\mathbf{N}_{2}$ & $80 \mathrm{~kg} \mathrm{~N} \mathrm{ha}^{-1}$ & 48.40 & 87.70 & 21.40 \\
\hline \multirow[t]{4}{*}{$\mathbf{N}_{3}$} & $100 \mathrm{~kg} \mathrm{~N} \mathrm{ha}^{-1}$ & 49.90 & 92.80 & 24.28 \\
\hline & SEm \pm & 0.47 & 0.65 & 0.19 \\
\hline & $\mathrm{CD}(\mathrm{P}=0.05)$ & 1.33 & 1.82 & 0.54 \\
\hline & $\mathrm{CV} \%$ & 6.83 & 5.08 & 5.99 \\
\hline
\end{tabular}

Table.2 Effect of irrigation and nitrogen on seed yield, stover yield and field water use efficiency (pooled)

\begin{tabular}{|c|c|c|c|c|}
\hline Tr No. & Treatments & $\begin{array}{l}\text { Seed yield } \\
\left(\mathrm{kg} \mathrm{ha}^{-1}\right)\end{array}$ & $\begin{array}{l}\text { Stover yield } \\
\quad\left(\mathrm{kg} \mathrm{ha}^{-1}\right)\end{array}$ & $\begin{array}{c}\text { Field water use } \\
\text { efficiency } \\
\left(\mathrm{kg} \mathrm{ha} \mathrm{mm}^{-1}\right)\end{array}$ \\
\hline & Irrigation: (I) & & & \\
\hline $\mathbf{I}_{1}$ & 0.4 IW:CPE ratio & 2734 & 7115 & 11.39 \\
\hline $\mathbf{I}_{2}$ & $0.6 \mathrm{IW}: \mathrm{CPE}$ ratio & 3317 & 8328 & 11.06 \\
\hline \multirow[t]{5}{*}{$\mathbf{I}_{3}$} & $0.8 \mathrm{IW}: \mathrm{CPE}$ ratio & 3185 & 8080 & 8.85 \\
\hline & SEm \pm & 54 & 123 & 0.18 \\
\hline & $\mathrm{CD}(\mathrm{P}=0.05)$ & 166 & 378 & 0.75 \\
\hline & $\mathrm{CV} \%$ & 12.11 & 10.85 & 12.22 \\
\hline & Nitrogen: (N) & & & \\
\hline $\mathbf{N}_{1}$ & $60 \mathrm{~kg} \mathrm{~N} \mathrm{ha}^{-1}$ & 2763 & 7034 & 9.38 \\
\hline $\mathbf{N}_{2}$ & $80 \mathrm{~kg} \mathrm{~N} \mathrm{ha}^{-1}$ & 3165 & 7950 & 10.75 \\
\hline \multirow[t]{4}{*}{$\mathbf{N}_{3}$} & $100 \mathrm{~kg} \mathrm{~N} \mathrm{ha}^{-1}$ & 3307 & 8540 & 11.16 \\
\hline & SEm \pm & 33 & 107 & 0.11 \\
\hline & $\mathrm{CD}(\mathrm{P}=0.05)$ & 93 & 302 & 0.32 \\
\hline & $\mathrm{CV} \%$ & 7.42 & 9.50 & 7.58 \\
\hline
\end{tabular}


Fig.1

\section{Days to 50\% flowering Days to maturity $\quad$ length of earhead $(\mathrm{cm})$}

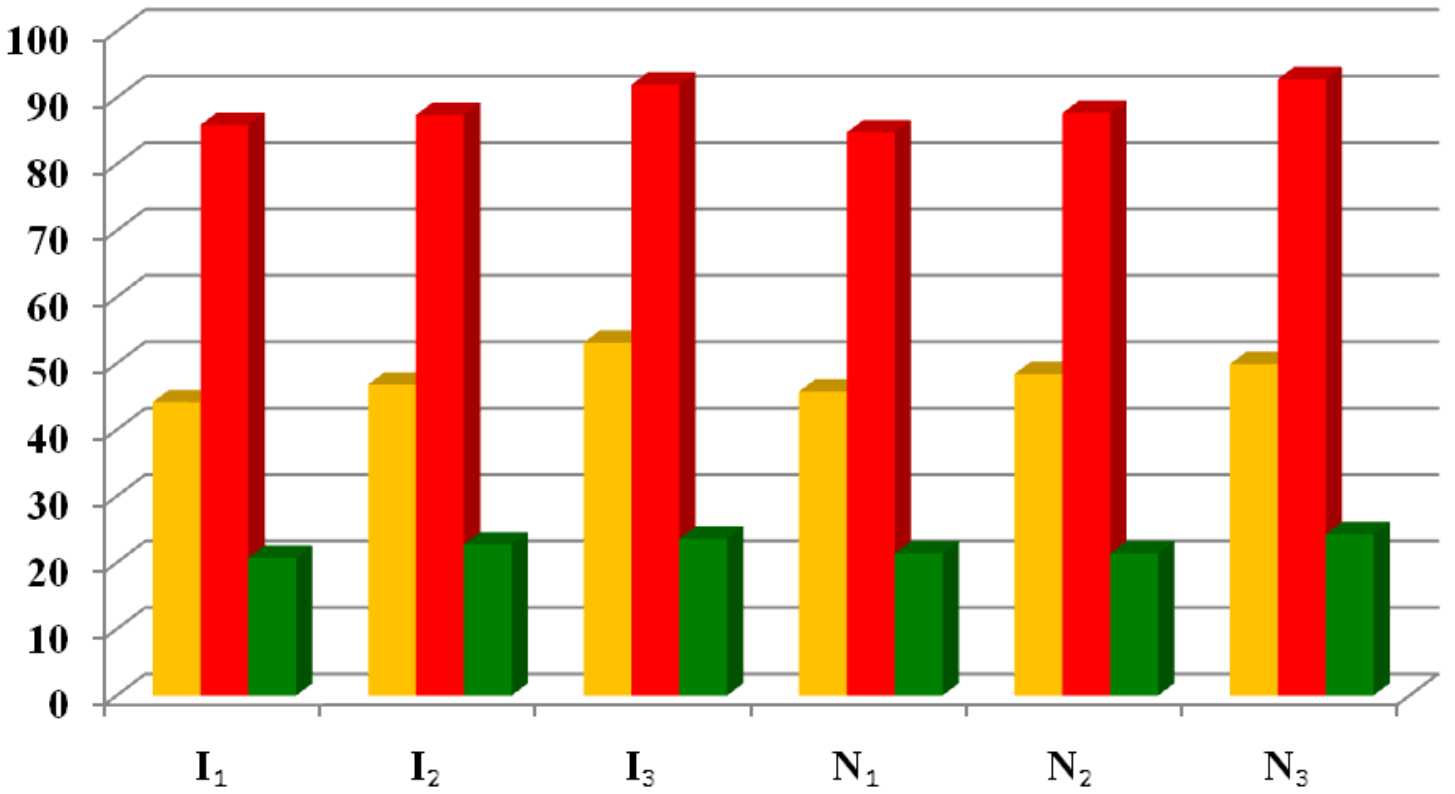

\section{Stover yield per hectare}

The results regarding stover yield per hectare of sorghum as influenced by different IW:CPE ratio and nitrogen are furnished in Table 2. Irrigation applied at $0.6 \mathrm{IW}$ :CPE ratio $\left(\mathrm{I}_{2}\right)$ produced significantly higher stover yield of $8328 \mathrm{~kg} \mathrm{ha}^{-1}$ followed by irrigating the crop at $0.8 \mathrm{IW}: \mathrm{CPE}$ ratio $\left(\mathrm{I}_{3}\right)$ which produced stover yield of $8080 \mathrm{~kg} \mathrm{ha}^{-1}$.

Significantly lower stover yield of $7115 \mathrm{~kg} \mathrm{ha}^{-}$ ${ }_{1}^{1}$ was recorded when sorghum was irrigated at an IW:CPE ratio of $0.4\left(\mathrm{I}_{1}\right)$. Application of nitrogen at $100 \mathrm{~kg} \mathrm{ha}^{-1}\left(\mathrm{~N}_{3}\right)$ gave significantly higher stover yield of $8540 \mathrm{~kg} \mathrm{ha}^{-1}$. Significantly lower stover yield of $7034 \mathrm{~kg} \mathrm{ha}{ }^{-}$ 1 was recorded under $60 \mathrm{~kg} \mathrm{~N}^{-1}\left(\mathrm{~N}_{1}\right)$. Significantly higher stover yields was found in treatment $\mathrm{I}_{3}$ (0.8 IW:CPE ratio) because of more photosynthesis and sufficient translocation due to adequate moisture availability.

\section{Field water use efficiency}

Data regarding water use efficiency as influenced by different IW:CPE ratio and irrigation are presented in Table 2. Result revealed that as IW:CPE ratio increased from 0.4 to 0.8 the FWUE in decreasing order. Higher FWUE of $11.39 \mathrm{~kg}$ ha $\mathrm{mm}^{-1}$ was noticed when sorghum was irrigated at 0.4 IW:CPE ratio. FWUE recorded under IW:CPE ratios of 0.6 and 0.8 were 11.06 and $8.85 \mathrm{~kg}$ ha $\mathrm{mm}^{-1}$, respectively. The higher FWUE in $\mathrm{I}_{1}$ than $\mathrm{I}_{2}$ might be due to slight coincidence of the irrigation schedules with critical stages of crop growth and development. Results revealed remarkable effect of nitrogen on 
FWUE. The mean values of FWUE recorded with three nitrogen levels viz., $\mathrm{N}_{1}\left(60 \mathrm{~kg} \mathrm{~N}^{-}{ }^{-}\right.$ $\left.{ }^{1}\right), \mathrm{N}_{2}\left(80 \mathrm{~kg} \mathrm{~N} \mathrm{ha}^{-1}\right)$ and $\mathrm{N}_{3}\left(100 \mathrm{~kg} \mathrm{~N} \mathrm{ha}^{-1}\right)$ were $9.38,10.75$ and $11.16 \mathrm{~kg}$ ha $\mathrm{mm}^{-1}$, respectively. These results are in conformation with the results reported by Bhuva and Sharma., 2015.

On the basis of above summarized results, the following conclusions have been drawn:

Increase in frequency of irrigation significantly delayed days to $50 \%$ flowering and maturity whereas, treatment $\mathrm{I}_{1} \quad(0.4$ IW:CPE ratio) noticed early flowering and maturity followed by treatment $\mathrm{I}_{2} \quad(0.6$ IW:CPE ratio).

Irrigating the crop at an IW:CPE ratio of 0.8 produced significantly maximum length of ear head.

Significantly higher seed yield and stover yield per hectare were recorded when sorghum was irrigated with $0.8 \mathrm{IW}: \mathrm{CPE}$ ratio $\left(\mathrm{I}_{3}\right)$.

Application of higher quantity of irrigation water reduced the water use efficiency. Sorghum irrigated at an IW:CPE ratio of 0.4 $\left(\mathrm{I}_{1}\right)$ increased the FWUE by $28.70 \%$ over 0.8 IW:CPE ratio respectively.

Higher dose of nitrogen exerted their significant influence on days to $50 \%$ flowering and maturity.

Significantly maximum length of ear head was recorded under $100 \mathrm{~kg} \mathrm{~N} \mathrm{ha}^{-1}\left(\mathrm{~N}_{3}\right)$ over lower dose of nitrogen $\left(\mathrm{N}_{1}\right)$. Higher dose of nitrogen recorded significantly higher seed and stover yield recorded under $100 \mathrm{~kg} \mathrm{~N} \mathrm{ha}^{-1}\left(\mathrm{~N}_{3}\right)$.

\section{References}

Bhuva, H. M. and Sharma, S. (2015). Influence of nutrient uptake by irrigation, nitrogen and phosphorus and their effect on quality parameters of rabi pearl millet. American- Eurasian Journal of Agricultural \& Environment Science 15 (3): 324-327. Hugar, A. Y., Jayadeva, H. M., Rangaswamy, B. R., Shivanna, S. and Chandrappa, $\mathrm{H}$. (2010). Assessing the effect of nitrogen and harvesting stages on yield and yield attributes of sweet sorghum genotypes. Agricultural Science Digest 30 (2): 139-141.

Mehmood, S., Bashir, A., Amad, A., and Akram, Z. (2008). Molecular characterization of regional

Sorghum bicolor varieties from Pakistan. Pakistan Journal of Biological 40: 2015-2021.

Patel G. J. (2005). Effect of irrigation and chemical fertilizer along with biofertilizer on crop production of maize (Zea maize L.), Ph. D. Thesis submitted to AAU, Anand.

Patel, M. R., Meisheri, T. G. and Sadhu, A. C. (2010). Effect of irrigation, nitrogen and bio- fertilizer on forage yield and quality of oat (Avena sativa L.). Forage Research 35 (4): $\quad$ 231-235.

\section{How to cite this article:}

Diksha Tajane, V. P. Usadadia, Dipak Borase and Sangita Sawadhkar 2019. Effect Of Irrigation and Nitrogen on Production Potential of Sorghum (Sorghum bicolor L.) under South Gujarat Condition. Int.J.Curr.Microbiol.App.Sci. 8(09): 1801-1806. doi: https://doi.org/10.20546/ijcmas.2019.809.208 